\title{
Deforestation increases differences in morphology and properties of dune soils located on contrasting slope aspects in the Torun military area (N Poland)
}

\author{
Piotr Sewerniak, Michal Jankowski \\ Nicolaus Copernicus University, Faculty of Earth Siciences, \\ Department of Soil Science and Landscape Management, \\ Lwowska 1,87-100 Toruń, Poland, \\ e-mail: sewern@umk.pl
}

\begin{abstract}
In a comparative research we investigated characteristics of soils situated on contrasting slope aspects (northern and southern) in two inland dune ecosystem types: 1 . dunes overplanted with a pine production forest and 2. dunes deforested for military purposes, where for some decades natural succession has been the main driver for vegetation development. We found that afforested dune slopes were entirely occupied by Podzols slightly varying by degree of development in respect to slope aspect what clearly changed after deforestation. Removal of forest distinctly predisposed dry south-facing dune slopes for erosion, which affected in truncation of Podzols. Nowadays, deforested southern slopes are covered by regenerating, weakly developed soils - Arenosols; while conditions prevailing on deforested northern slopes preserve Podzols. Such situation implies distinct increase of primarily existing differences in characteristics of soils of opposite slope aspects such as moisture, temperature and organic carbon stocks.
\end{abstract}

Key words: inland dunes, soils, forest succesion, heathlands, slope aspect.

\section{Introduction}

Slope aspect is an ecological factor which significantly influences soil characteristics (e.g. Prusinkiewicz, 1961; Szafranek, 1992; Seibert et. al., 2007). This was reported also to inland dunes in spite they are not huge landforms (Jankowski, 2010; Sewerniak et al., 2011). The differences in soil parameters are usually relatively slight when dunes are overgrown by a forest as such vegetation mitigates relief-conditioned microclimatic differences and uniformly affects soils of various slope aspects by litterfall. In this paper we aimed to present a general pattern of changes in soil characteristics which followed deforestation of inland dunes in the Torun military ground.

\section{Study area}

The research was conducted in the Torun military ground located south of Torun $\left(52^{\circ} 55^{\prime} \mathrm{N}, 18^{\circ} 36^{\prime} \mathrm{E}\right)$. The area is situated in one of the biggest inland dune fields of Central Europe, formed in periglacial conditions of Late Pleistocene. Podzols developed under fresh Scots pine (Pinus sylvestris) forest Peucedano-Pinetum as climax vegetation (Chojnacka et al., 2010) are dominant soils for the investigated dune field. The studied area is characterized by mean annual temperature $7.5^{\circ} \mathrm{C}$ and relatively low precipitation which averages at $520 \mathrm{~mm}$ for a year (Wójcik \& Marciniak, 2006). 


\section{Materials and methods}

The research was parallel conducted in two study plots: 1. located in a central part of the military area; actually the ground is covered by vegetation of natural, secondary succession due to former deforestation for military purposes which took place ca. 60 years ago; however since then some fires occurred in the plot (the last one in turn of $1970 \mathrm{~s}$ and 1980s), 2. located in a buffer zone for military activities, in a 135 years old pine production forest. Both plots were chosen to be located on latitudinally situated dunes of a relative height of ca. $15 \mathrm{~m}$. In the middle part of northern and southern slopes of the dunes soil characteristics were investigated in terms to: thickness of soil horizons, organic carbon (OC) content and actual moisture as well as temperature of mineral topsoil at a depth of $3 \mathrm{~cm}$ for noon time of a standard sunny summer day (26.07.2013). Analyzed dunes were chosen for the research as being representative for both studied ecosystem types. The shown in the paper regularities were also recognized for other dunes of the studied area.

\section{Results and discussion}

On the investigated dune located in a pine forest podzolization was distinctly expressed (by occurrence of AE and Bhs horizons) in morphology of soils on both studied slopes (Fig. 1). Amplitudes of soil actual moisture and temperature as well as thickness of an organic horizon and OC stocks were also rather slight for the dune overplanted with a forest while after deforestation the differences have

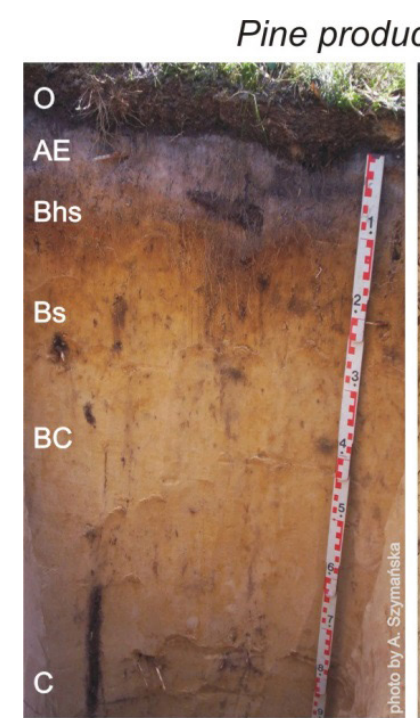

Slope N

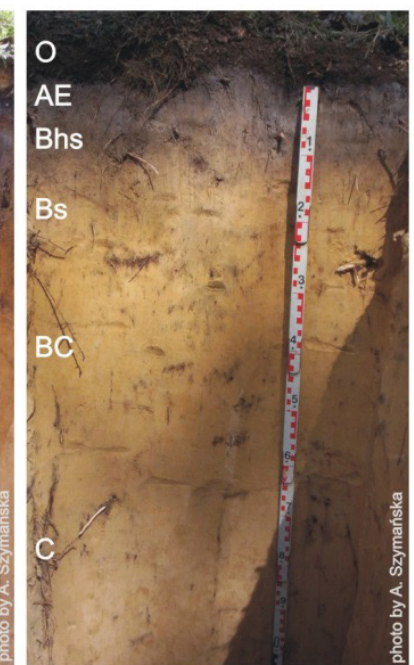

Slope S

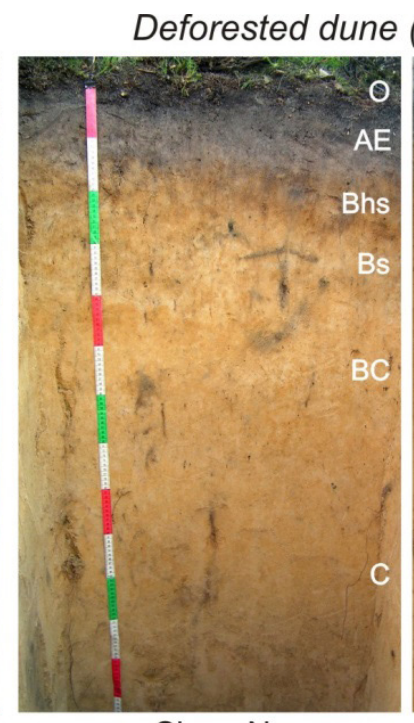

Slope N

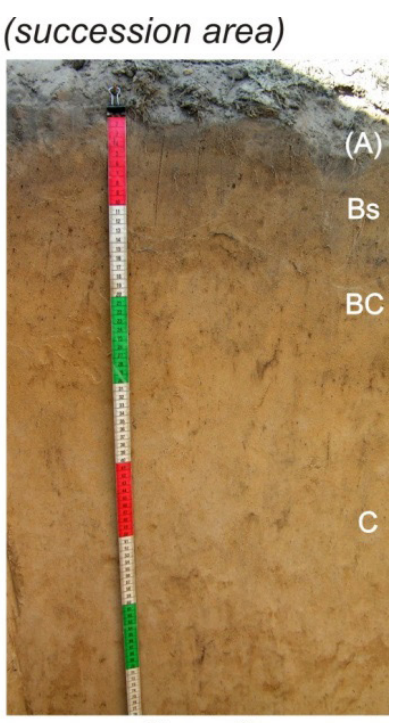

Slope S

Figure 1. Morphology of the investigated soils

\section{Actual soil moisture} at a depth of $3 \mathrm{~cm}$ (26.07.2013, [\%])

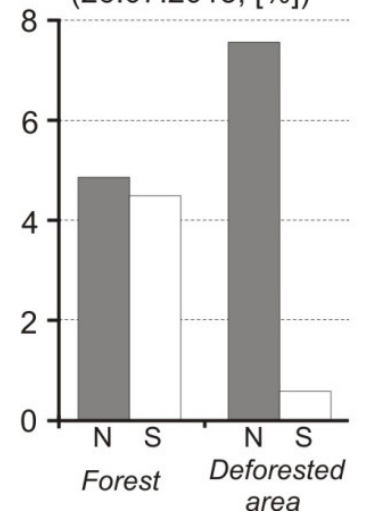

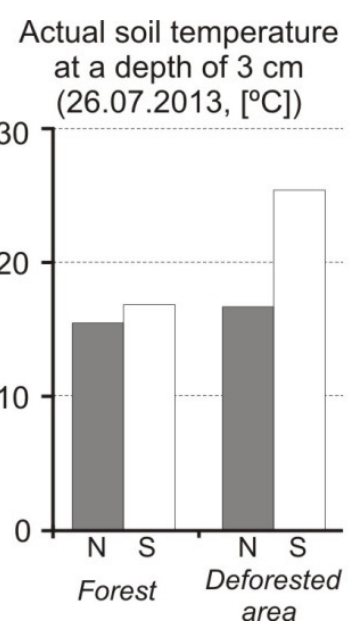

Thickness of an organic horizon [cm]

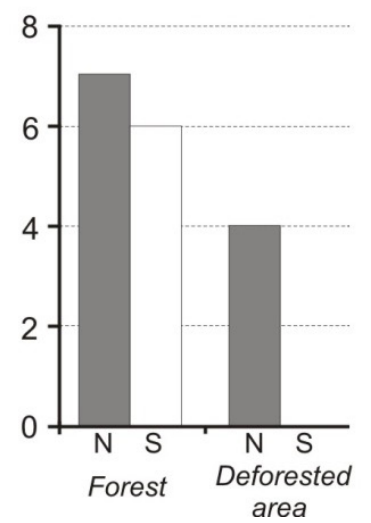

OC stocks for the $0-20 \mathrm{~cm}$ mineral layer $\left[\mathrm{kg} \cdot \mathrm{m}^{-2}\right]$

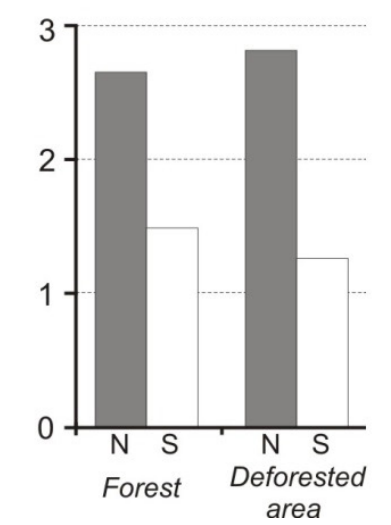

Figure 2. Some characteristics of the studied soils (abbreviations: OC - organic carbon, $\mathrm{N}$ - northern slope, $\mathrm{S}-$ southern slope) 
distinctly increased for contrasting slope aspects (Fig. 2). Southern slopes as much drier after forest removal became much more unfavour for recolonization by plants and thus more susceptible for organic horizon degradation and also erosion.

The stated differences in morphology, typology and properties of soils of contrasting slope aspects have distinct effect to ongoing natural succession in the studied military area. Namely, mosaics of naturally restoring plant associations strictly follow relief in the dune area studied (Jankowski, 2010, Sewerniak \& Mendyk, 2015). This issue will be presented in details in another paper.

\section{Acknowledgments}

We thank to Aneta Szymańska and Justyna Śmigielska for their help in field and laboratory works. The research was financed by the Polish Ministry of Science and Higher Education (project N N305 304840).

\section{References}

Chojnacka J., Cyzman, W., Nienartowicz, A. \& Deptuła, M., 2010, Variability of the structure and directions in the development of heaths and psammophilous grasslands within the artillery range near the city of Torun, Ecological Questions, 12: 87-125.
Jankowski M., 2010, Some aspects of site conditions of heathlands in the Torun Basin, Ecological Questions, 12: $145-151$.

Prusinkiewicz Z., 1961, Zagadnienia leśno-gleboznawcze na obszarze wydm nadmorskich Bramy Świny [Forest-pedological issues in a coastal dune area in the Świna Gate], Bad. Fizjogr. nad Polską Zach., 7: 25-127.

Seibert J., Stendahl J., Sørensen R., 2007, Topographical influences on soil properties in boreal forests, Geoderma, 141: 139-148.

Sewerniak P., Mendyk Ł., 2015, Secondary succession of trees in the dune landscape of the "Glinki" long-term research area - analysis with GIS, For. Res. Pap., 76(2): $122-128$.

Sewerniak P., Bednarek R. \& Szymańska A., 2011, Preliminary studies on the influence of dune-slope exposure on a pine forest ecosystem in the Torun Basin, For. Res. Pap. 72: 37-46.

Szafranek A., 1992, Wpływ rzeźby terenu i skały macierzystej na kształtowanie się gleb z piaskowców dewońskich i triasowych regionu świętokrzyskiego [The effect of the area relief and the parent rock on formation of soils developed from Devonian and Triassic sandstones of the Świętokrzyski region], Rocz. Glebozn. 1/2: 121131.

Wójcik G., Marciniak K., 2006, Klimat [Climate], [in:] L. Andrzejewski, P. Weckwerth, Sz. Burak (eds.), Toruń i jego okolice. Monografia przyrodnicza [The city of Torun and the surroundings, Nature monograph], Wyd. UMK, Toruń: 99-128. 